\title{
MODIFICATION OF CELLULOSE AND LIGNOCELLULOSE MATERIALS WITH NANOCLUSTERS OF COPPER FERROCYANIDES
}

\author{
Chuiko Institute of Surface Chemistry of National Academy of Sciences of Ukraine \\ 17 General Naumov Str., Kyiv, 03164, Ukraine, E-mail:v.galysh@gmail.com
}

A possibility of obtaining of new combined sorbents based on bleach cotton fiber and lignocellulose complex from apricot stones modified with nanoclusters of copper ferrocyanides [FC]Cu has been studied. A relation has been found between the modifier concentration in the initial solution, its content in the obtained combined sorbents, size agglomerates, and sorption capacity for ${ }^{137} \mathrm{Cs}$. It has been found that in terms of practical significance, the content of the modifier in the bulk of organic carriers about 4-4.5\% provides high sorption capability of synthesized materials for radiocaesium. The most efficiency of use of [FC]Cu mass in sorption of ${ }^{137} \mathrm{Cs}$ corresponds to combined sorbents containing 2-2.5\% [FC]-phase.

Keywords: combined sorbent, copper ferrocyanide, cellulose, lignocellulose, radiocaesium, recovery rate, distribution coefficient

\section{INTRODUCTION}

Rapid development of the chemical industry is connected with contamination of biosphere with stable and radioactive elements. The main part of radioactive emissions and liquid radioactive wastes of chemical production are long-lived radionuclides such as caesium-137 [1]. Modern methods of decontamination of aqueous solutions require different sorption materials of organic or inorganic nature. However, the sorption capacity of the predominant majority of these sorbents is largely determined by composition of the solution and the $\mathrm{pH}$ range limiting the area of their practical application. Ferrocyanides of $d$-metals ([FC]Me, where $\mathrm{Me}$ - metal cations) are effective sorbents of radiocaesium in a wide $\mathrm{pH}$ range, that show a high sorption capacity for ${ }^{137} \mathrm{Cs}$ from both individual and high saline solutions [2]. The main factor that limits the practical use of such salts is final microcrystalline form. Most of the methods developed for producing of [FC]-sorbents consist in impregnation of inorganic matrices characterized by high specific surface area with solutions of [FC]Me [3-5]. As a result of such treatment, combined materials are obtained with a high content of the modifier in the bulk of carrier. Such combined materials are characterized by low retention capacity of modifier phase in the bulk of matrix that can be washed out in aqueous solutions.
In this regard, it is important to develop efficient combined sorbents with low content of [FC]Me in the matrix that should provide their high sustained maintenance in the bulk of carrier and high sorption characteristics. A solution of this problem can be use of natural polymers of fibrous or powder structure with low specific surface area as a carrier of [FC]-phase. Cellulose and lignocellulose (LC) can be regarded as such materials. Modification of natural plant polymers with nanoclusters of [FC]Me should allow us to obtain combined sorbents with high sorption and selective properties towards radiocesium.

[FC]-sorbents based on cellulose and LCcomplex can be used as materials of multifunctional purposes. The resistant combined fibrous sorbents obtained can be used as a filter material for industrial application for decontamination of low-level liquid wastes from ${ }^{137} \mathrm{Cs}$, for the concentration of ${ }^{137} \mathrm{Cs}$ from residues of nuclear power plants in order to reduce the volume of solid wastes and from water environmental objects for the following analytical determination. Powdered modified LC-complexes can be used as enterosorbents of radionuclides in medicine and veterinary.

The aim of this study is the synthesis and comparative characterization of combined sorbents based on polymer components of plant material modified with nanoclusters of $[\mathrm{FC}] \mathrm{Cu}$. 


\section{MATERIALS AND METHODS}

The bleached cotton fiber (BCF) and LCcomplex from apricot stones were used as a carrier (matrix) of [FC]-phase. The content of the main chemical components in initial raw materials are described in Table 1.

Table 1. Chemical composition of plant polymer materials, $\%$

\begin{tabular}{lcc}
\hline \multirow{2}{*}{ Components } & \multicolumn{2}{c}{ Raw materials } \\
\cline { 2 - 3 } & BCF & $\begin{array}{c}\text { Apricot } \\
\text { stones }\end{array}$ \\
\hline cellulose & $99 \pm 1$ & $40 \pm 0.3$ \\
lignin & $<0.5$ & $50 \pm 0.5$ \\
ethanol-benzene & absent & $7 \pm 0.1$ \\
extractives & & \\
hot-water solubility & absent & $9 \pm 0.1$ \\
ash & $<0.1$ & $<2.0$ \\
\hline
\end{tabular}

BCF were used for modifying without any preparatory operations. Apricot stones were grounded to a size of $0.12 \mathrm{~mm}$ and were treated by acid-alkali scheme which consisted in hydrolysis of raw material with $3.0 \mathrm{~N}$ solution of hydrochloric acid and subsequent activation of obtained product with $0.3 \mathrm{~N}$ solution of sodium carbonate. Both stages were carried out for $60 \mathrm{~min}$ at $100{ }^{\circ} \mathrm{C}$. At the end of mentioned processing operations LCproduct was separated from the solution by filtration, washed with distilled water at $80{ }^{\circ} \mathrm{C}$ to achieve neutral medium and dried at $50{ }^{\circ} \mathrm{C}$ to constant moisture of 5-7\%.

Modification of cellulose and LC-complex with solution of $[\mathrm{FC}] \mathrm{Cu}$ at the different concentrations and investigation of sorption properties towards ${ }^{137} \mathrm{Cs}$ were done according to the procedures described in [6].

Particle size of $[\mathrm{FC}] \mathrm{Cu}$ in solutions was determined by photon correlation spectroscopy (FCS) on a ZetaSizer-3 (Malvern Instruments,
Great Britain) laser correlation spectrometer equipped with He-Ne laser LGN-111 (P = $25 \mathrm{mV}$, $\lambda=633 \mathrm{~nm}$ ), range measurement of device was from $1 \mathrm{~nm}$ to $20 \mu \mathrm{m}$.

Characteristics of porous structures of the initial materials were determined by lowtemperature nitrogen adsorption-desorption at $77 \mathrm{~K}$ using a NOVA 2200 (Quantachrome, USA) gas adsorption analyzer. Samples degassing conditions - $140{ }^{\circ} \mathrm{C}, 20 \mathrm{~h}$. The specific surface area was calculated by BET (Brunauer, Emmett, Teller) method [7].

\section{RESULTS AND DISCUSSION}

In our previous research [8] the effect of basic technological parameters of synthesis of combined materials on their properties was investigated. It has been found that effective [FC]-sorbents with high sorption capacity to ${ }^{137} \mathrm{Cs}$ are obtained at neutral $\mathrm{pH}$ values and the process temperature of $90^{\circ} \mathrm{C}$. It was also shown that increasing the modifier concentration naturally leads to an increase in the content of inorganic component in the bulk of carrier and the sorption properties but specific sorption parameters significantly decreased. Therefore, it is necessary to study the regularities of [FC]-cluster formation in the modifier depending on its concentration and to study its sorption and selective capability for caesium.

The study on size of $[\mathrm{FC}] \mathrm{Cu}$ clusters in the initial solution for modification by the FCS showed that the particles of modifiers were presented in solution not as separate crystallites but in the form of agglomerates. It was found that at the concentration of modifier in the initial solution of $1 \mathrm{~g} / \mathrm{l}$ these agglomerates were characterized by predominant size of $41 \mathrm{~nm}$ (Fig. 1).

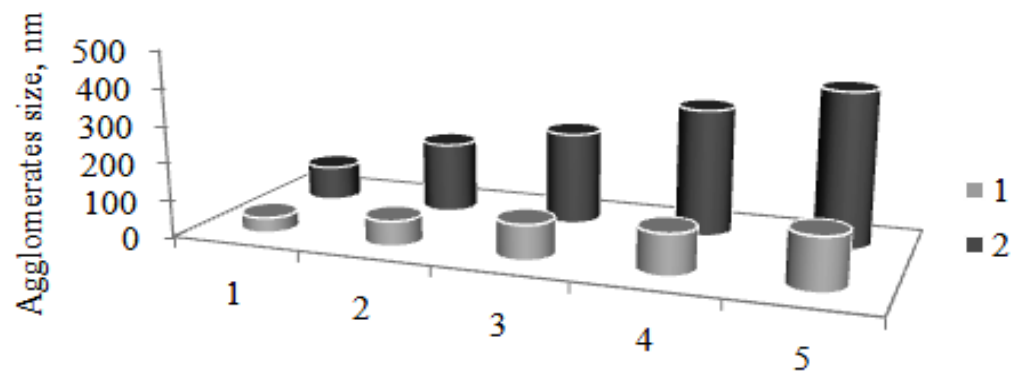

Concentration of $[\mathrm{FC}] \mathrm{Cu}, \mathrm{g} / 1$

Fig. 1. Dependence of [FC]Cu-agglomerates on the modifier concentration: 1 - initial solution; 2 -after modification 
It is known that the size of individual crystallites of [FC]Me is $8-10 \mathrm{~nm}[2,6]$. So it can be argued that the structure of agglomerates formed at the modifier concentration of $1 \mathrm{~g} / \mathrm{l}$ includes approximately $4-5$ crystallites. The increasing of the modifier concentration in the initial solution from 1 to $5 \mathrm{~g} / \mathrm{l}$ leads to agglomeration of inorganic particles, resulting in the increasing of predominant size of formed [FC]-agglomerates to $145 \mathrm{~nm}$ (Fig. 1, curve 1), the number of crystallites in the agglomerates at the same time increases to $15-18$. Obtained results indicate that the dependence of the size of $[\mathrm{FC}] \mathrm{Cu}$-agglomerates on the concentration of modifier in the initial solution for the modification is almost linear within the range of investigated concentrations. Subsequent heating of [FC]-solutions during the modification of $\mathrm{BCF}$ or LC-complex is accompanied by further agglomeration of inorganic particles that results in increase of average size of [FC]-particles in 3 times for all the concentrations studied (Fig. 1, curve 2). Modification of the BCF and LC with $[\mathrm{FC}] \mathrm{Cu}$ colloid solutions under heating leads to the immobilization of inorganic phase on the organic surface with formation of combined BCF-[FC]Cu and $\mathrm{LC}-[\mathrm{FC}] \mathrm{Cu}$ sorbents.

It has been found that the increase of the modifier concentration in the initial solution from 1 to $4 \mathrm{~g} / \mathrm{l}$ promotes the growth of modifier content up to $70 \%$ for both types of plant polymer carriers as shown in Fig. 2. As can be seen from the presented in Fig. 2 data, the content of [FC]Cu in combined sorbents based on LC is $30 \%$ higher in the entire range of studied concentrations than that for $\mathrm{BCF}$ matrix due to the larger specific surface area. According to the results obtained, the values of specific surface area for BCF and LC-complex are 2 and $7 \mathrm{~m}^{2} / \mathrm{g}$ respectively. Further increase in the concentration of $[\mathrm{FC}] \mathrm{Cu}$ in solution is not accompanied by changes in the volume of modifier content in BCF and LC carrier. As was shown, the size, and therefore weight, of [FC]Cu agglomerates increase linearly with the growth of the modifier concentration, so it is natural that the dependence of the content of inorganic phase in the bulk of $\mathrm{BCF}$ and LC matrices on the modifier concentration in solution in the range $1-4 \mathrm{~g} / \mathrm{l}$ is also linear.

Investigation of the sorption properties of the obtained materials toward radiocaesium shows that increasing the content of $[\mathrm{FC}] \mathrm{Cu}$ in the carrier of $\mathrm{BCF}$ from 1.0 to $2.7 \%$ causes an increase the recovery rate of ${ }^{137} \mathrm{Cs}$ by $10 \%$ (Fig. $3 a$ ).

Next change in the content of inorganic component up to $3.5 \%$ does not influence on this parameter much. Maximum value of recovery rate of microamounts of caesium from individual aqueous solutions of $98.2 \%$ corresponds to BCF$[\mathrm{FC}] \mathrm{Cu}$ with modifier content $4.1 \%$ obtained at the concentration of the modifier $3 \mathrm{~g} / \mathrm{l}$. At the same time, the values of recovery rate of ${ }^{137} \mathrm{Cs}$ growth twice with a change of the content of [FC]-phase in the bulk of carrier from 1.3 to $3.5 \%$ for LCsorbents. Maximum recovery rate of radiocesium from solutions of $94.6 \%$ is achieved by combined sorbent, obtained at the same conditions, with the content of $[\mathrm{FC}] \mathrm{Cu}$ in the bulk of matrix $4.5 \%$. Such difference in the sorption properties of obtained combined materials based on different polymer carriers is also can be connected with structural features of BCF and LC.

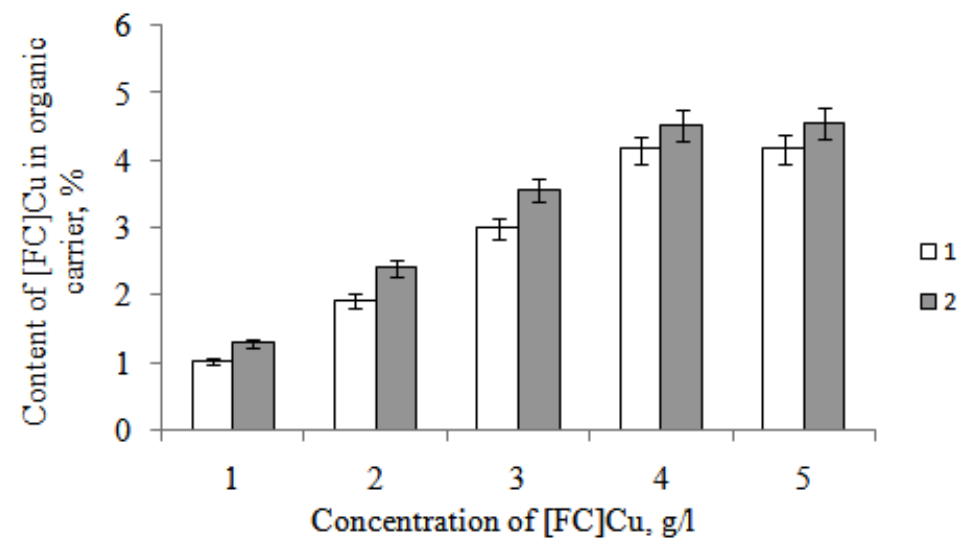

Fig. 2. The influence of the modifier concentration on the content of [FC]-phase in the bulk of carrier: $1-\mathrm{BCF}$; $2-\mathrm{LC}$ complex 


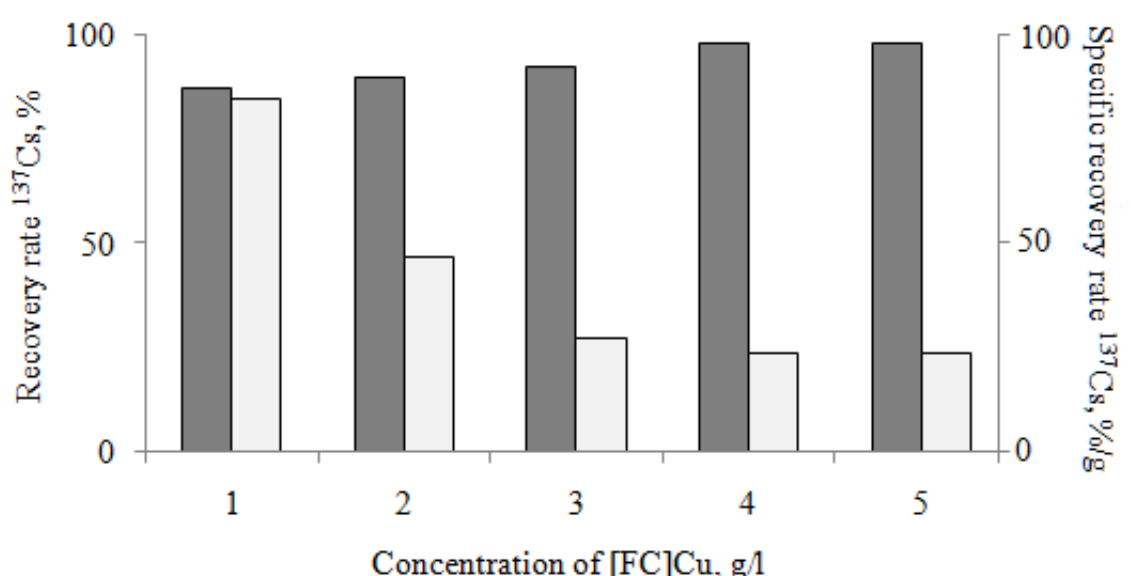

$a$

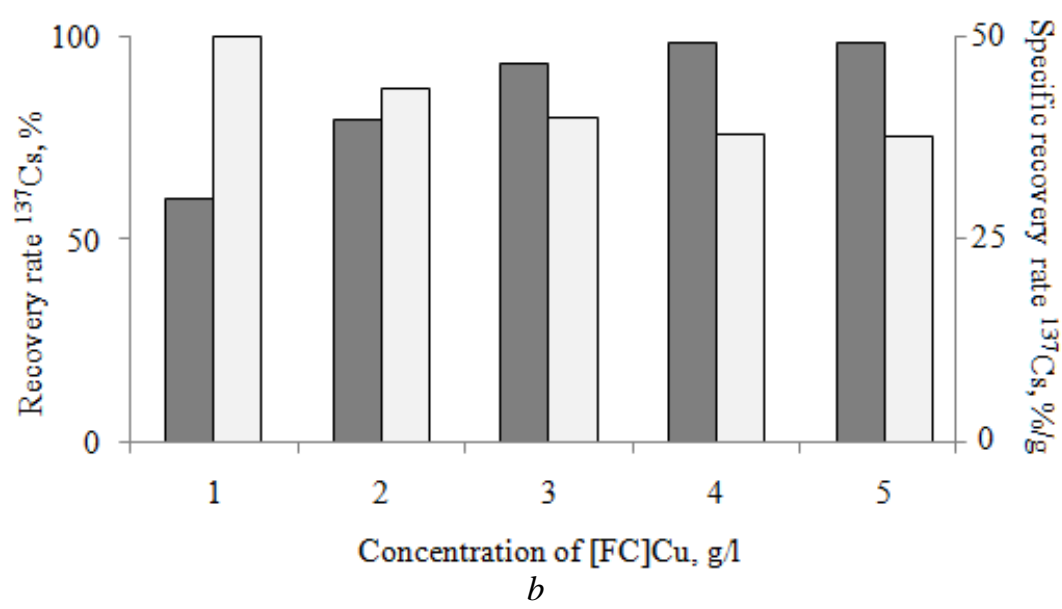

Fig. 3. Dependence of recovery rate ( $\square)$ and specific recovery rate ( $\square$ ) of caesium-137 for synthesized sorbents on the modifier concentration: $a-\mathrm{BCF}-[\mathrm{FC}] \mathrm{Cu} ; b-L C$-[FC]Cu

Unlike recovery rate, the distribution coefficient for ${ }^{137} \mathrm{Cs}$ varies linearly with increasing modifier content in the bulk of carriers from 1.0 to $4.1 \%$ for BCF and from 1.3 to $4.5 \%$ for LC (Fig. 4).

This means that increase of $[\mathrm{FC}] \mathrm{Cu}$ concentrations in solution from 1 to $4 \mathrm{~g} / \mathrm{l}$ leads to the improvement of this parameter doubled for both types of combined sorbents. Obtained results shows that the maximum distribution coefficient 7620 and $7020 \mathrm{ml} / \mathrm{g}$ corresponds to a combined sorbents based on BCF and LC respectively and synthesized by the modifier concentration $4 \mathrm{~g} / \mathrm{l}$. Next change of the modifier concentration to $5 \mathrm{~g} / \mathrm{l}$ does not cause the change in sorption ability of $\mathrm{BCF}-[\mathrm{FC}] \mathrm{Cu}$ and $\mathrm{LC}-[\mathrm{FC}] \mathrm{Cu}$ toward radiocaesium.

Results of assignment of distribution coefficient ${ }^{137} \mathrm{Cs}$ from aqueous solutions and to the mass of $[\mathrm{FC}] \mathrm{Cu}$ in the sample of sorbents indicate that the increase of the content of the inorganic phase causes a decrease of specific values of these parameters (Fig. 4). In other words, the increase in the size of the inorganic [FC]-agglomerates in the bulk of organic carriers leads to the reducing of the efficiency of use of $[\mathrm{FC}] \mathrm{Cu}$ mass in cesium sorption. The maximum specific distribution coefficient for cesium corresponds to the samples of combined BCF and LC sorbents with the content of inorganic component of 1.0 and $1.3 \%$ respectively and with the predominant size of $[\mathrm{FC}] \mathrm{Cu}$ agglomerates in the bulk of carrier $95 \mathrm{~nm}$. As can be seen from the presented in Fig. $4 a$ data, specific distribution coefficient on combined BCF$[\mathrm{FC}] \mathrm{Cu}$ is reduced by $30 \%$ only with the next agglomeration of [FC]Cu to the size of $190 \mathrm{~nm}$. In the case of LC-[FC]Cu (Fig. $4 b$ ), specific distribution coefficient ${ }^{137} \mathrm{Cs}$ decreases by $40 \%$ linearly with the further increase in the size of inorganic agglomerates in the bulk of both matrices to $340 \mathrm{~nm}$. It can be explained by the fact that agglomeration of the modifier particles is accompanied by a decrease in the specific surface 
of $[\mathrm{FC}] \mathrm{Cu}$ phase, and thus the total amount of active sorption sites determining the selectivity of inorganic component of combined sorbents toward radiocaesium.

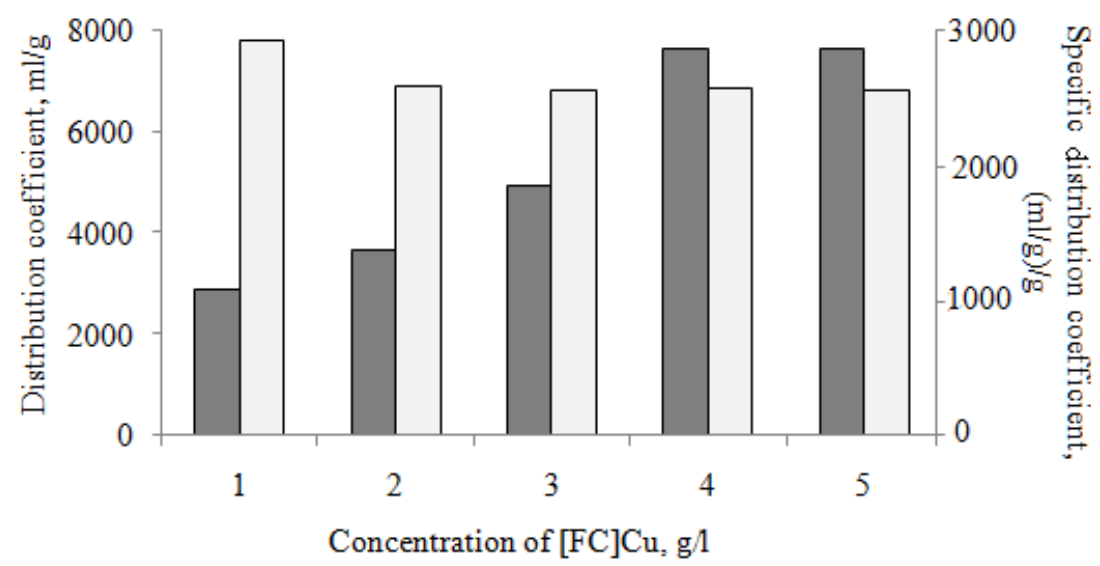

$a$

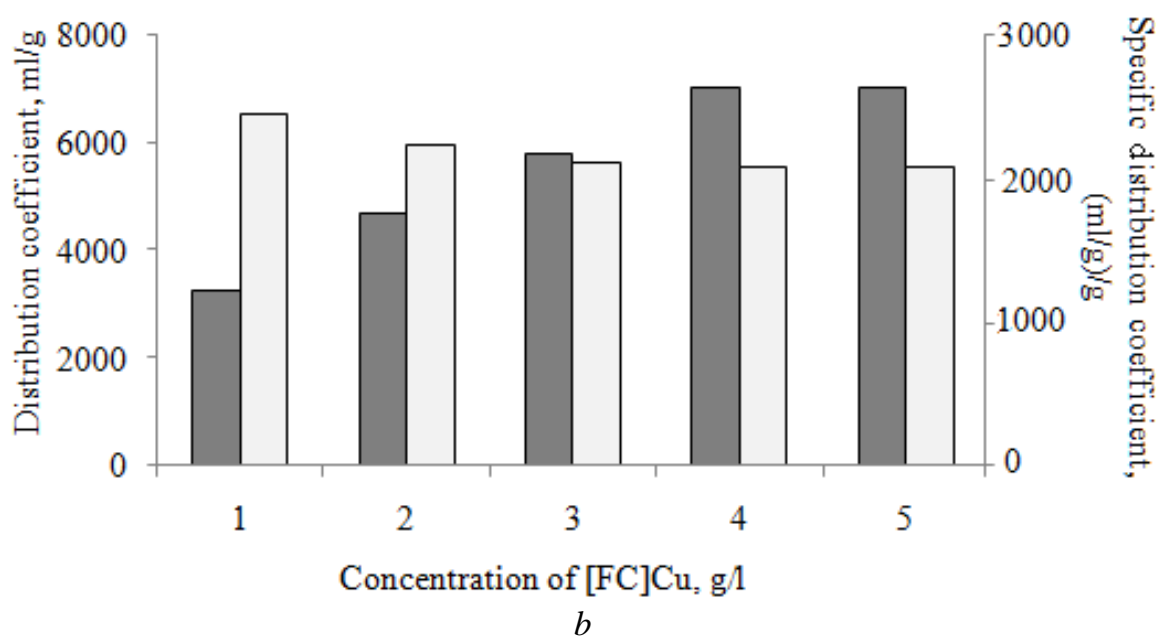

Fig. 4. Dependence of caesium-137 distribution coefficient ( $\square$ ) and specific distribution coefficient ( $\square$ ) of synthesized sorbents on the modifier concentration: $a-\mathrm{BCF}-[\mathrm{FC}] \mathrm{Cu} ; b-L C-[\mathrm{FC}] \mathrm{Cu}$

\section{CONCLUSIONS}

Thus, the parameters of modification of plant polymer components with the solution of $[\mathrm{FC}] \mathrm{Cu}$ have been studied in detail. The dependence between the modifier concentration in the initial solution for modification, size of its agglomerates, the content in the bulk of BCF and LC matrices and sorption capacity for ${ }^{137} \mathrm{Cs}$ have been found. It has been determined that although the increase in the content of [FC]-phase in the bulk carrier provides some increase efficiency and selectivity of extraction (distribution coefficient), but specific indicators of sorption capacity of sorbents obtained for ${ }^{137} \mathrm{Cs}$ so is significantly reduced. And it is not feasible to prepare composite sorbents with high content of [FC]-phase because that the excess of the modifier can be washed out in aqueous solutions. Obviously, the content of [FC]Me 2-2.5\% mass in composed LC matrix seems to be the best to create composite adsorbents for effective removal of radioactive cesium from solutions.

Acknowledgement. This research was supported by a Marie Curie International Research Staff Exchange Scheme Fellowship within the $7^{\text {th }}$ European Community Framework Programme, project PIRSES-GA-2011-295260, "ECONANOSORB" and by Programme of National Academy of Sciences of Ukraine "Fine Chemicals". 


\section{Модифікування целюлозних і лігноцелюлозних матеріалів нанокластерами фероціаніду міді}

\section{В.В. Галиш, М.Т. Картель}

Інститут хімії поверхні ім. О.О. Чуйка Національної академії наук України вул. Генерала Наумова, 17, Київ, 03164, Україна, v.galysh@gmail.com

Вивчено можливість отримання нових комбінованих сорбентів на основі вибіленого бавовняного волокна і лігночелюлозного комплексу з абрикосових кісточок, модифікованих нанокластерами фероціаніду міді. Встановлено залежність між конщентрачією модифікатора у вихідному розчині, вмістом в отриманих комбінованих сорбентах, розміром його агломератів та сорбиійною здатністю щзодо ${ }^{137}$ Cs. 3'ясувалося, ще з точки зору практичного застосування, вміст модифікатора в об'ємі органічних носіїв 4-4.5\% забезпечує високу сорбиійну здатність синтезованих матеріалів щодо радіоцезію. Найбільша ефективність використання маси [ФЦ]Си при сорбиії ${ }^{137}$ Сs відповідає комбінованим сорбентам, що містять [ФЦ]-фазу на рівні 2-2.5\%.

Ключові слова: комбінований сорбент, ферочіанід міді, иелюлоза, лігночелюлоза, радіочезій, ступінь вилучення, коефіиієнт розподілу

\section{Модифицирование целлюлолозных и лигноцеллюлозных материалов нанокластерами ферроцианида меди}

\section{В.В. Галыш, Н.Т. Картель}

Институт химии поверхности им. А.А. Чуйко Национальной академии наук Украинь ул. Генерала Наумова, 17, Киев, 03164, Украина, v.galysh@ gmail.com

Изучена возможность получения новых комбинированных сорбентов на основе отбеленого хлопкового волокна и лигночеллюлозного комплекса из абрикосовых косточек, модифицированных нанокластерами ферроцианида меди. Обнаружена зависимость между концентрацией модификатора в исходном растворе, содержанием в полученных комбинированных сорбентах, размером его агломератов и сорбиионной способностью по отночению ${ }^{137}{ }^{13}$. Выяснилось, что $c$ точки зрения практического использования, содержание модификатора в объеме органических носителей 4-4.5\% обеспечивает высокую сорбиионную способность синтезированных материалов по отнотению к радиочезию. Наибольшая эффективность использования массы [ФЦ]Си при сорбиии ${ }^{137}$ Cs соответствует комбинированным сорбентам, содержащих [ФЦ]-разу на уровне 2-2.5\%.

Ключевые слова: комбинированный сорбент, феррочианид меди, челлюлоза, лигноцеллюлоза, радиочезий, степень извлечения, коэффичиент распределения 


\section{REFERENCES}

1. Vasilenko I.Y., Vasilenko O.I. Radioactive cesium, Energy: economy, technics, ecology, 7 (2001) 16 (in Russian).

2. Tananaev I.V., Seifer G.B., Kharitonov Yu.Ya. et al. Chemistry of Ferrocyanides, Moscow, Khimiya Publ., 1971, 320 p. (in Russian).

3. Voronina A.V., Semenishchev V.S., Nogovitsyna E.V. et al. A study of ferrocyanide sorbents on hydrated titanium dioxide support using physiochemical methods, Radiochemistry, 54 (2012) 69.

4. Panasyugin A.S., Golikova N.B., Strukova O.V. Concentrating radiocesium with selective sorbents, Radiochemistry, 45 (2003) 290.

5. Sangvich T., Sukwarotwat V., Wiacek R.J. et al. Selective capture of cesium and thallium from natural waters and simulated wastes with copper ferrocyanide functionalized mesoporous silica, J. Hazard. Mater., 182 (2010) 225.

6. Galysh V.V., Kartel M.T., Milyutin V.V. et al. Composite cellulose-inorganic sorbents for ${ }^{137}$ Cs recovery, J. Radioan. Nucl. Chem., 301 (2014) 315.

7. Brunauer S., Emmett P.H., Teller E. Adsorption of gases in multimolecular layers, J. Am. Chem. Soc., 60 (1938) 309.

8. Galysh V.V., Kartel M.T., Milyutin V.V. Synthesis and sorption properties of combined cellulose-inorganic sorbents for the concentration of cesium-137, Surface, 5 (2013) 135.

Received 16.09.2014, accepted 17.09.2014 